\section{Ankara University Faculty of Educational Sciences Journal of Special Education}

2022, 23(2), 389-407
RESEARCH

Recieved Date: 13.01.21

Accepted Date: 28.07.21

OnlineFirst: 18.09 .21

\title{
Effect of the Complex Exercises in Hemsball on Attention and Coordinative Skills of Adolescents with Hearing Loss*
}

\author{
Meltem Işsk ${ }^{(D)} 1$
}

\author{
İbrahim Kılıç $\mathbb{D}^{2}$
}

\begin{abstract}
Introduction: In this study the objective was to determine the effects of the complex exercises in hemsball on the attention and coordinative skills among adolescents with hearing loss.

Method: 20 hearing-impaired students were divided into two groups as experimental and control. A training program consisting of the complex exercises in hemsball was applied to adolescents with hearing loss for one hour, three days per week, for a period of 10 weeks. Bourdon Attention Test, Simple Reaction Time Test and balance test of Bruininks-Oseretsky Motor Profiency (BOT-2) motor competence sub-items and Alternate Hand Wall Toss Test for hand-eye coordination measurements were utilized for data collection. In the analysis of the data, descriptive statistics and two factor analysis of variance for repeated measures were used for the difference between pre-test and post-test average values for each group.

Findings: While significant effect of complex exercises in hemsball on attention, hand-eye coordination, balance and reaction test (dominant hand) was observed in the experimental group, no significant difference was noted in the mean values of the reaction test (non-dominant hand).

Discussion: It is especially important to develop and promote exercise programs tailored to the needs of adolescents with hearing loss with attention and coordination issues.

Conclusion: The complex hemsball exercises indicated in this study should be considered as an alternative game for adolescent with hearing loss in terms of attention, focus and concentration, hand-eye-foot coordination, balance and reaction time.
\end{abstract}

Keywords: Hemsball, hearing loss, exercise, attention, bot-2, coordination, reaction time.

To cite: Işık, M., \& Kılıç, İ. (2022). Effect of the complex exercises in hemsball on attention and coordinative skills of adolescents with hearing loss. Ankara University Faculty of Educational Sciences Journal of Special Education, 23(2), 389-407. https://doi.org/10.21565/ozelegitimdergisi.859721

*This study was supported by the Scientific Research Projects Commission of Afyon Kocatepe University (Project No: 17. BESYO.04).

${ }^{1}$ Corresponded Author: Assist. Prof., School of Physical Education and Sport, Afyon Kocatepe University, E-mail: isik.meltem@adu.edu.tr https://orcid.org/0000-0002-1372-9322

${ }^{2}$ Prof., Department of Biostatistics, Afyon Kocatepe University, E-mail: kilicibrahim@ @otmail.com, https://orcid.org/0000$\underline{0003-0595-8771}$ 


\section{Introduction}

Individuals with hearing loss are one of the disadvantaged groups who cannot acquire sufficient basic motor skills. Hearing loss is an inability to hear that differs from a very mild degree to a profound degree (Genç, 2019). According to the World Health Organization (WHO) a person who is not able to hear as well as someone with normal hearing - hearing thresholds of $20 \mathrm{~dB}$ or better in both ears - is said to have hearing loss (WHO, 2021). Children with hearing disabilities go through similar stages with children who hear from primary stages of motor development, such as sitting, crawling, assisted walking, unsupported walking. However, depending on the cause and degree of hearing loss, it is observed that they are less in balance, equivalent reactions, and skills related to muscle coordination (Olszewska \& Trzcińska, 2010; Rine et al., 2004; Üçüncü \& Kütükcü, 2014). The vestibular system, located in the inner ear in the sense of hearing, plays a vital role in ensuring (maintaining) the body's upright position and balance when walking. Problems that may occur in muscle control and balance due to vestibular system in hearing loss also negatively affect muscle strength and motor functions (Kegel et al., 2010; Rajendran \& Roy, 2011; Shah et al., 2013). Some studies on motor skills in deaf children have shown that there is a decrease in static and dynamic balance, general dynamic coordination, visual motor skills and ball catching skills, and significant differences in reaction times and movement speeds (Chilosi et al., 2010; Dummer et al., 1996; Melo et al., 2019; Potter \& Silverman, 1984; Rine et al., 2004; Savelsbergh et al., 1991; Siegel et al., 1991). One of the basic coordination skills used during daily motor activities is maintaining balance (Stanek et al., 2015). Failure to receive auditory sensations results in the lack of coordination among the most common movements as the body balance control is impaired. This is because the auditory system and vestibular system are interconnected. If any of these systems are affected, they can affect the balance (Patel et al., 2017). Postural development and delayed motor development is a common sensorimotor disorder in children with hearing loss (Anna \& Magdalena, 2008; Kimitaka, 1999). The correction and improvement of postural control is accepted as a prerequisite for the realization of movement skill performance (Foundriat et al., 1993). Therefore, people with hearing loss should be encouraged to participate in regular physical activity and to do special exercises that especially improve strength and balance (Assaiante et al., 2005). Ensuring consistency of training and exercise in sportive activity will be effective in dynamic and static postural control of these people throughout the day (Ayanniyi et al., 2014; Patel et al., 2017; Perrin et al., 2002). Attention is a self-evident mental phenomenon that is active during every single moment of awareness (Mancas, 2016). It is noted that people with hearing loss often have difficulty focusing on a sound source and filtering out unwanted sources (Gatehouse \& Akeroyd, 2006). It is reported that many students who acquire hearing loss after birth have attention problems compared to their peers with congenital hearing loss. In the studies conducted in the United States and Yugoslavia, children with hearing loss show higher levels of attention deficits compared to their hearing peers (Kelly et al., 1993). Theunissen et al. (2014) reported that children with hearing disabilities showed significantly more attention deficits than their peers with typical hearing. In children with hearing loss, situations such as not following the topic being spoken, not being able to continue the dialogues on the subject, and being distracted very quickly are observed frequently. Güneş (1997) emphasized that the main factors affecting attention refer to the lack of ability to see and hear well. Most of the learning process occurs, primarily through auditory and visual interaction. If these critical senses do not function effectively, the learning process can be compromised, and attention deficit can often be seen as a side effect of this situation (Michaëlis, 2013). Although studies show that children with hearing loss show attention deficit, there are not many studies investigating the effect of physical exercise on attention deficit in these children. Various exercise programs, such as walking, running, jumping, and ball games were found to alleviate the characteristic symptoms in children with attention deficits (Jeyanthi et al., 2019).

The most important factor that ensures the development of children's motor activity, basic physical characteristics and strengthening of organisms is the game. Hemsball, a new sport and playable by everyone, requires excellent hand-eye-foot coordination to catch and serve the ball. In addition, there should be high focus and concentration on the opponent's movements during the game, balance while catching the ball, and reaction speed to counter the shots delivered by the opponent (Iş1k \& Zorba, 2020). International hemsball juniors pitch and hemsball materials are shown in Figure 1. 


\section{Figure 1}

International Hemsball Juniors Pitch and Hemsball Materials

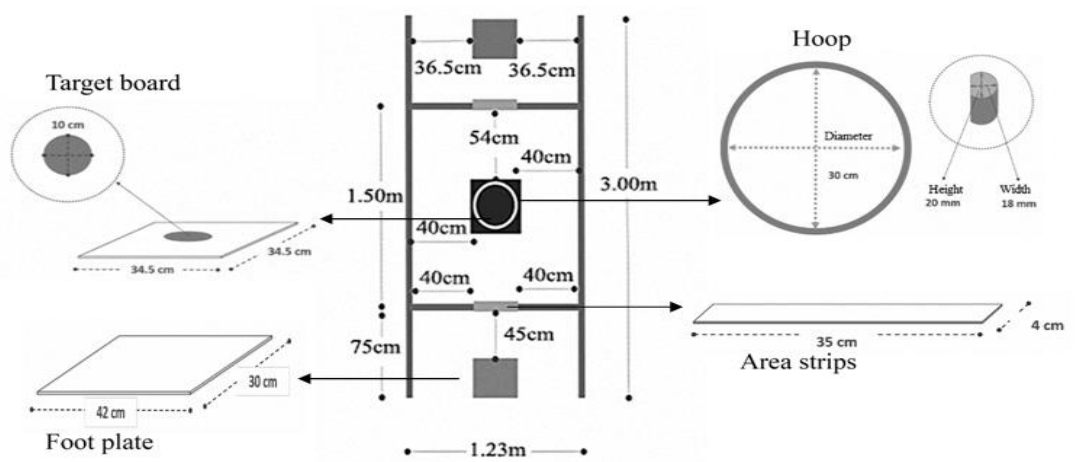

Materials used in hemsball include a ball (rubber, $55 \mathrm{~mm}$ in diameter, weighing $95 \mathrm{gr}+2$ ), hoop (diameter $30 \mathrm{~cm}$, width $18 \mathrm{~mm}$., height $20 \mathrm{~mm}$ ), target board (dimensions of $34.5 \times 34.5 \mathrm{~cm}$ ), foot plate (dimensions of $42 \times$ $30 \mathrm{~cm}$ or $50 \times 40 \mathrm{~cm}$ ) and area strips (measuring 4 x $35 \mathrm{~cm}$ ) (Işık \& Zorba, 2020). The hemsball is shown in Figure 2 , and practical shots with multiple balls are shown in Figure 3.

\section{Figure 2}

Hemsball

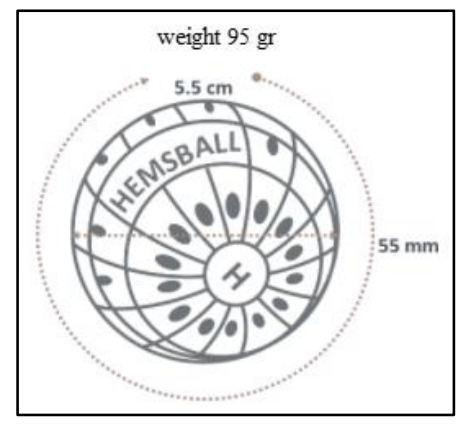

Figure 3

Practice Shooting with Multiple Balls

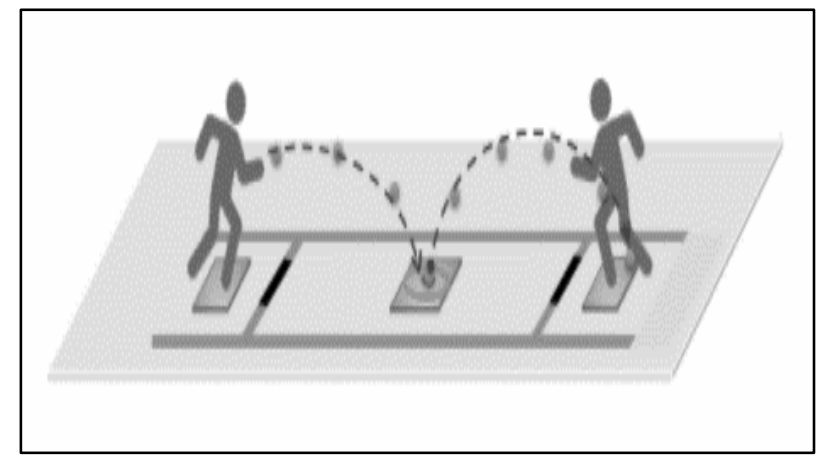

The purpose of the hemsball is first to throw the ball into the hemsball circle to make it bounce into the competitor's court. The opponent has to catch the ball to prevent a point from being scored. Complex exercises, which include coordination exercises and exercises with multiple balls, enable the active use of both hands regardless of the dominant hand. These exercises have an important role in the hemsball skills. It is thought that complex exercises in hemsball will have a significant and positive impact on adolescents' attention and coordination capacity with hearing loss. In this context, the study to be carried out is essential in demonstrating the effect on adolescents' attention and coordinative competence with hearing loss. In this study, the objective was 
to determine the effects of the complex exercises in hemsball on the attention and coordinative skills among adolescents with hearing loss.

\section{Method}

\section{Design of the Study}

This study was designed as a pre-test/post-test experimental design. In this two-factor experimental design, the first factor is groups (experiment and control), and the second factor is repeated measurements (pretest and post-test). In this design, a respondent is included only in one of the experiment or control groups (Ural \& K1lıç, 2011). In this context, this research is a randomized controlled experimental study. In the study, groups are independent variables, while dependent variables are attention, reaction time, balance, and alternate hand wall toss tests.

\section{Participants}

The data group of the study consisted of 12-16 years old adolescents who attended the Karahisar Hearing Impaired School and Kütahya Hearing Impaired School in the cities of Afyonkarahisar and Kütahya. Inclusion criteria in selecting the students were (i) having a normal intelligence range, (ii) having hearing level referring to $56 \mathrm{~dB}$ or more, (iii) absence of an additional disability, (iv) lack of sports background and attending school. Inclusion criteria in the study were evaluated with the information obtained from student documents in schools. The experimental group of the study consisted of 10 adolescents who attended Karahisar Hearing Impaired School and the control group of the study consisted of 10 adolescents who attended Kütahya Hearing Impaired School. Cluster sampling method was used in the study and each school was considered as a cluster. Assignment to the experimental and control groups was done using the random sampling method. A total of 20 adolescents with hearing loss were included in the study. Parents of adolescents with hearing loss involved in the study signed written informed consent. A meeting was conducted with the parents of the participating adolescents before the initiation of the hemsball exercises. Information was given about the content of the hemsball exercise program at the meeting. This study was carried out as a result of the decision of Afyon Kocatepe University Scientific Research and Publication Ethics Committee dated 31.03.2017 and numbered 35095782-050.01.04-. Moreover, this study was supported by the Scientific Research Projects Commission of Afyon Kocatepe University (Project No: 17. BESYO.04). The distribution of the individuals in the experimental and control groups according to their gender and age are presented in Table 1.

\section{Table 1}

Distribution of Individuals According to Gender and Age

\begin{tabular}{lccccc}
\hline \multirow{2}{*}{ Variables } & & \multicolumn{2}{c}{ Control group } & \multicolumn{2}{c}{ Experiment group } \\
\cline { 2 - 6 } Gender & Girl & $n$ & 50 & 6 & 60 \\
& Boy & 5 & 50 & 4 & 40 \\
& 12 & 5 & - & 2 & 20 \\
Age & 13 & - & 20 & 2 & 20 \\
& 14 & 2 & 50 & 4 & 40 \\
\hline Total & 15 & 5 & 30 & 10 & 20 \\
\hline
\end{tabular}

In the study, the distribution of participants in the experimental and control groups by gender was equal, while $60 \%$ of the experimental group consisted of girls. On the other hand, the mean age values of the students in control (age: 14.1) and experiment (age: 13.6) group were close to each other.

\section{Exercise Program}

Hemsball was first designed by Altınay in 2011. It was accepted as a sport branch by the Turkish Republic Youth and Sports Ministry in 2013. Turkish Sports for All Federation started coaching courses for hemsball in 2014. In these coaching courses and seminars, hemsball game rules, throwing techniques and hemsball practices were first introduced by Altınay and his team practically (Hemsball, n.d.). Her Yaş için Spor Hemsball (Sport Hemsball for All Ages), including game rules, techniques and practices was first published in 2017 (Gönülateş, 2017). The complex exercise program in the study was adapted from the hemsball exercises (Gönülateş, 2017; Hemsball, n.d.) to the adolescents with hearing loss. The studies were carried out by students attending the faculty of sports sciences, who have a hemsball coaching certificate and receive sign language training. 
Featuring both quantitative changes in materials and variations in practice, the exercise program consisted of 1 hour of the complex exercises of hemsball with the duration of three days per week for 10 weeks. While the children included in the experimental group were given a 1-hour hemsball complex exercise program after school, the control group attended only physical education classes. Hemsball complex exercise program in the experimental group is presented below.

\section{Hemsball Complex Exercise Program}

The warm-up exercises included the following: (1) Throwing the ball into the air with the right hand and catching it with the left hand and vice versa. (2) Throwing the ball into the air after rotating it clockwise with three fingers and catching it in mid-air with the same/other hand. (3) Bouncing the ball on the ground with feet fixed and changing hands. (4) Bouncing the ball going back and forth. (5) Throwing the ball against a wall with one hand and changing hands above head level. (6) Sitting two meters from a wall and throwing the ball against the wall and catching it with the same/other hand.

The hemsball exercises included the following: (1) Moving away from the wall and throw the hemsball in sequence into three hoops from a distance of three meters. (2) A student standing in the center of hoops arranged in a circle turns clockwise to throw a ball into each hoop and catch it. (3) Hemsball balls are held in each hand and thrown simultaneously on the ground and caught with the other hand. (4) A student standing on the foot plate one meter from the target board in front of a wall holding a hemsball throws the ball at the red dot on the target board and catches the ball returning from the wall. (5) Two students each hold a hemsball and stand three meters apart from each other. They throw the balls simultaneously at each other with an upward curve and try to catch the oncoming ball. (6) The same exercise is done by bouncing the ball on the ground. (7) A student facing the wall at a distance of two meters holds a ball in each hand, throws them simultaneously at the wall and catches the returning balls. (8) A student facing the wall at a distance of two meters throws the hemsball balls. (s) He is holding in one hand consecutively at the wall and continues to catch them with the same hand. (9) A student holds two hemsball balls in one hand and throws them consecutively into the air and continues the exercise actively with one hand while keeping one ball in the air all the time without dropping it. (10) A student has two balls in one hand and one ball in the other, and throws them consecutively into the air and catches them (juggling). It includes the task of stretching.

\section{Data Collection}

Data were collected through attention and coordinative skill tests. Attention levels of the adolescents with hearing loss were measured with Bourdon Attention Test (Brickenkamp et al., 1975; Brunner, 2006) and coordinative skill levels with Simple Reaction Time Test (Davis \& Fang, 1993), Bot-2 Balance Test (Bruininks \& Bruininks, 2005) and Alternate Hand Wall Toss Test (Du Toit et al., 2011) for hand-eye coordination. The reaction test was evaluated in milliseconds. The Bourdon attention test, Bot-2 balance test and Alternate hand wall toss test were evaluated as a score.

\section{Bourdon Attention Test}

Developed by Bourdon in 1955, this test aims to measure individuals' attention levels. The papers given to adolescents with hearing loss consisted of 407 letters and 20 lines arranged at certain and regular intervals. The test papers contained the letter a (150 pcs), g (75 pcs), b (50 pcs) and d ( 25 pcs). Each section lasted five minutes. The adolescents were asked to underline the indicated letters by following each line in a given time. The test was evaluated by counting the letters underlined when the time was over. The highest points to be taken from the test were 118 points (Brunner, 2006). The Cronbach Alpha coefficient for the Bourdon attention test was reported as 0.78 by Karaduman (2004).

\section{Simple Reaction Time Test}

At the time of measurement, the adolescents were given a quiet room with sufficient light from which distracting factors were removed. Three repetitions were carried out for both the right and left forefingers to test for reaction to light. During the test, the eyes were focused on the screen to keep the head $40 \mathrm{~cm}$ behind the screen. The adolescents were asked to hold the button about $1 \mathrm{~cm}$ above the button using their right and left hands and the forefinger. Visual reaction times less than $150 \mathrm{~ms}$ were considered to be the expected response, while visual reaction times longer than $500 \mathrm{~ms}$ were considered as significant errors. Both were excluded from the analyses. Visual reaction time (ms) was expressed as mean and standard deviations (Dane \& Erzurumluoğlu, 2003). The Cronbach Alpha coefficient for the simple reaction time test was reported as 0.93 by Hamsher and Benton (1977). 


\section{BOT-2 Balance Test}

Bruininks-Oseretsky test of motor proficiency balance tests was comprised of nine parts (1. Standing on a line with eyes open and feet at a forward angle, 2. Walking forward on a line, 3. Standing on a line with one leg and eyes open, 4. Standing on a line with eyes closed and feet at a forward angle, 5. Walking forward on a line on tiptoes and heels, 6. Standing on a line with one leg and eyes closed, 7. Standing on balancing equipment with one leg and eyes open, 8. Standing on balancing equipment with the tip of a foot touching a heel, 9. Standing on balancing equipment with one leg and eyes closed). The scores recorded during the test procedure were the raw scores of the adolescents. After the test was completed, these raw scores were converted into point scores and then into points obtained. The conversion scale given in the personal registration form was used to convert raw points to point scores. The point score was recorded in the circle on the first right of the personal registration form. The total motor score was calculated as the best score for the BOT-2 balance test which was 37 (Mülazımoğlu-Ball, 2006). The Cronbach Alpha coefficient for the BOT-2 balance test was reported as .87 by Bruininks (1978).

\section{Alternate Hand Wall Toss Test}

The Wilson brand tennis ball and the Casio HS-80TW-1DF brand chronometer were used in the application of the Alternate Wall Hand Toss for hand-eye coordination. The platform was prepared in accordance with the test protocol. Stanley 1-30-487 brand strip meters were used to measure the reach distances of the participants. A line was drawn two meters from a wall. The respondent was asked to face the wall and take a position with legs separated at shoulder width and bent at the knee. (S)he was asked to throw a tennis ball at the wall with his right or left hand and catch it with his/her other hand. The respondent was given 30 seconds and the successful catches were recorded. (S)he was allowed to have three tries and the best score was recorded. The necessary calculations according to the scores indicated in the scoring table were done correctly in accordance with the purpose. The ability to catch according to the table was evaluated as very good over 35 and as weak under 15. Measurements were made three days before the start of the work and three days after the end of the work. Volunteer interpreters with sign language certificates explained to all adolescents how the measurements would be taken and experiment measurements were made to the whole study group before the essential measurements so that the learning would take place. The environment in which the measurements were performed was quiet and the adolescents were not distracted. Reliability and validity data were not found for the alternate hand wall toss test.

\section{Data Analysis}

Individual characteristics of adolescents with hearing loss were described in terms of frequency $(f)$ and percent $(\%)$ distribution. The results of Kolmogorov-Simirnov and Shapiro-Wilk tests showed that the data exhibited normal distribution $(p>.05)$. In this context, the effect of hemsball throwing techniques used with the adolescents who constituted the sample group of the study was evaluated by using a two factor (group $\mathrm{x}$ time) variance analysis for the repeated measures while significance level was determined as .05. However, as a result of analysis of variance, group and time interaction was not significant. Therefore, in order to examine the differences in detail, differences between the groups were analyzed by independent samples $t$ test and differences between pretest and posttest were analyzed by paired samples $t$ test. The data were analyzed with SPSS 18.0.

\section{Results}

The findings regarding the effect of complex hemsball exercises on the attention and coordinative competence of adolescents with hearing loss were presented in Table 2. According to Table 2, there was a significant difference between the attention, hand-eye coordination, balance and reaction (dominant hand) pre-test and post-test average values of the experiment group $(p<.05)$. 
Table 2

Findings Regarding the Effect of Complex Hemsball Exercises on the Attention and Coordinative Competence

\begin{tabular}{|c|c|c|c|c|c|c|}
\hline \multirow{2}{*}{ Variables } & \multirow{2}{*}{ Groups } & \multicolumn{2}{|c|}{ Pre-test } & \multicolumn{2}{|c|}{ Post-test } & \multirow[b]{2}{*}{$p$} \\
\hline & & $\bar{X}$ & $S D$ & $\bar{X}$ & $S D$ & \\
\hline \multirow{3}{*}{$\begin{array}{l}\text { Attention test } \\
\text { (highest score 118) }\end{array}$} & Experimental & 88.10 & 19.39 & 107.50 & 11.25 & .006 \\
\hline & Control & 89.20 & 18.13 & 89.60 & 19.34 & .443 \\
\hline & $p$ & \multicolumn{2}{|c|}{.897} & \multicolumn{2}{|c|}{.021} & \\
\hline \multirow{3}{*}{$\begin{array}{l}\text { Hand-eye coordination test } \\
(\text { very good }>35 \text { weak }<15)\end{array}$} & Experimental & 7.30 & 3.83 & 13.30 & 4.27 & .000 \\
\hline & Control & 11.80 & 8.91 & 12.10 & 9.19 & .193 \\
\hline & $p$ & \multicolumn{2}{|c|}{.061} & \multicolumn{2}{|c|}{.713} & \\
\hline \multirow{3}{*}{$\begin{array}{l}\text { BOT-2 subtest (Balance) } \\
\text { (the best score } 37 \text { ) }\end{array}$} & Experimental & 28.30 & 2.40 & 33.90 & 2.64 & .000 \\
\hline & Control & 25.80 & 4.66 & 26.40 & 4.74 & .051 \\
\hline & $p$ & \multicolumn{2}{|c|}{.149} & \multicolumn{2}{|c|}{.001} & \\
\hline \multirow{3}{*}{$\begin{array}{l}\text { Reaction test (ms) } \\
\text { (Dominant Hand) }\end{array}$} & Experimental & 51.30 & 7.87 & 38.30 & 6.34 & .000 \\
\hline & Control & 43.00 & 10.61 & 42.80 & 10.22 & .437 \\
\hline & & \multicolumn{2}{|c|}{.053} & \multicolumn{2}{|c|}{.255} & \\
\hline Reaction test (ms) & Experimental & 49.80 & 10.05 & 41.70 & 8.11 & .085 \\
\hline \multirow[t]{2}{*}{ (Nondominant Hand) } & Control & 49.10 & 10.98 & 49.40 & 10.26 & .638 \\
\hline & $p$ & \multicolumn{2}{|c|}{.884} & \multicolumn{2}{|c|}{.080} & \\
\hline
\end{tabular}

The difference between all pretest and posttest averages was not significant in the control group $(p>.05)$. The mean values in the experimental group revealed that attention increased from 88.10 to 107.50 while hand-eye coordination increased from 7.30 to 13.30 and balance from 28.30 to 33.90 and the reaction score decreased from 51.30 to 38.30 . Furthermore, according to the average values of the attention and coordination skills in pre-test, no significant difference was found between the experiment and control groups in attention $(p>.05)$, significant differences were found between the post-test of experiment and control group in attention, hand-eye coordination and balance $(p<.05)$. On the other hand, no significant difference was found between the experiment and control group in terms of both pre-test or post-test mean values of non-dominant hand $(p>.05)$.

\section{Discussion}

This study was carried out to determine the effects of hand-eye coordination, attention, reaction and balance-focused complex exercises on the coordination abilities among students with hearing loss. The sample consisted of 20 students with the age range of 12 to 16. Complex exercises (Gönülateş, 2017; Hemsball, 2016) included coordination exercises and exercises with multiple balls. They enabled the active use of both hands as they had an important place in the hemsball skill. Therefore, in this study, the hemsball complex exercises were utilized (Gönülateş, 2017; Hemsball, n.d.) to observe whether they contributed to the development of attention and coordinative abilities in the students with hearing loss.

In the evaluation of the attention and coordinative skills of adolescents with hearing loss, it was observed that the attention, hand-eye coordination and balance of the experimental group increased significantly. Hemsball complex exercises detected a significant and positive effect on the reaction time of the dominant hand. These exercises did not statistically have any significant difference on the reaction time of the non-dominant hand.

There are studies which examine the effects of the hemsball on the pysco-physical development of the children with low intellectual disabilities and multiple disabilities (Todorova et al., 2014) and on the balance, reactive agility and lower extremity power in typically-developing individuals (Sever et al., 2016). The first detailed study examining the effects of the hemsball on motor development in people with disabilities was conducted by author (Iş1k, 2016). The study aimed to define the effect of hemsball on balance, dual coordination and upper extremity coordination in children with intellectual disability. It was reported that a training program for hemsball with a duration of 12 weeks had positive effects on the motor abilities in low and medium level among children with intellectual disability (Işık \& Zorba, 2020).

Hearing loss may have an impact on the development of motor skills. In the hearing loss, the degree of development of motor skills including harmony and coordination of movements, depends on the ability to compensate for deficits through the use and training of other sensory organs (Walowska et al., 2018). In this study, it is not surprising that complex hemsball exercises positively contributed to balance development among adolescents with hearing loss. One of the basic coordinative skills used in daily motor activities is to maintain 
balance. Butterfield (1991) stated that balance was a crucial skill in determining the movement and functioning. Walowska et al. (2018) found that exercises performed according to the original physical activity program based on modified pilates exercises were significantly more effective in improving body balance control among the participants with hearing loss between 13 and 24 years of age. Majlesi et al. (2014) concluded that training sessions consisting of two categories, such as stability and static-dynamic balance activity training emphasizing somatosensory awareness, could lead to decreased postural oscillations and increased balance among children with hearing loss. Kurt (2007) examined the effects of regular exercise on balance parameters in typically developing children and those with hearing loss, showing that the balance of individuals with hearing loss can be improved by regular exercise. Silsupadol et al. (2006) reported that a 10-12-hour balance training program was effective in increasing balance performance. Chilosi et al. (2010) noted that severe and profound hearing loss affected many areas of children's development, including the static and dynamic balance reaction, coordination and speed of movement. Sever et al. (2016) found that the balance scores of the children following the 8-week hemsball training improved.

The development of motor skills, including coordination and compatibility of movement, is based on the ability of the hearing impaired to compensate deficiencies with the use of other sensory organs (Walowska et al., 2018). Therefore, the promotion of motor physical activities to improve coordination is considered particularly important in this group. The wall exercises included in the hemsball complex exercise program require predicting the rotation speed and height of the thrown ball, as well as the angle of rotation and evaluating it in a short time. In addition, it increases the difficulty by grasping the ball with one hand and limiting it to the wall. Although the exercises are simple, it raises the motivation of acquiring coordinative skills.

Tetik et al. (2016) studied a number of motor characteristics of individuals with hearing loss according to age groups and reported that the group including the participants who were 16 year-olds had the lowest scores for hand and foot reaction times and movement speed. In addition, researchers emphasized that reaction time which developed according to age decreased with regular physical activity and increased the performance (Tetik et al., 2016). The working group in the study of Rine et al. (2004) consisted of 21 children with hearing loss who participated in a special 12-week (three trainings per week) training program with 30 minutes of hand-eye coordination, general coordination activities, visual motor training and balance training per session that emphasized visual and somatosensory awareness. The researcher stated that exercise intervention focusing on motion strategies may halt the progression of motor development delay. Yurdakul et al. (2012) found that movement instruction had a positive effect on attention and memory development. Akandere et al. (2010) examined the effects of educational game applications on the attention level of children in the physical education class. The authors reported that the educational game program applied to the 9-13 age group for 8 weeks affected the attention level and that the attention values of the trial group of the educational game program were higher than those of the control group. Tunç et al. (2014) concluded that the attention levels of adolescents who participated in golf exercise practices improved positively.

It is especially important to develop and promote exercise programs tailored to the needs of people with hearing loss with impaired coordination (Gheysen et al., 2008; Melo et al., 2015; Rajendran \& Roy, 2011; Walowska et al., 2018). This is because exercise programs are generally prepared according to the needs of the person or group. Therefore, the complex hemsball exercises in this study were prepared according to the necessary skills such as hand-eye coordination, attention, reaction and balance to meet the children with hearing loss needs. The complex hemsball exercises in this study should be considered as an option for people with hearing loss in terms of attention, coordination, reaction time and balance as they assess the ability to prepare for the speed and direction of the ball coming from a specified area and throwing the ball into the hoop in the center.

\section{Conclusion}

This study aimed to determine the effects of complex exercises in hemsball on attention and coordination skills in hearing-loss adolescents. It showed that the hemsball game had a positive effect on students' attention and coordination competence with hearing loss. The sport of Hemsball can play a big role in eliminating the psychosocial need which is a significant issue for the hearing loss population. In Hemsball, the rule of shooting on the same target board with the opponent can positively affect the sense of sharing. During the training, if the player throws the ball into the target ring and moves to correct the ring, it may help to increase the awareness of cooperation. In addition, the rule that the player who loses the toss at the beginning of the game takes the first throw may encourage respect for the opponent. Therefore, future studies can also be carried out in the psychosocial field. The limitations of the study were the inclusion of one school for the hearing impaired in only two 
cities, the use of bourdon attention test, simple reaction time test, BOT-2 balance test, alternate hand wall toss tests, the age range of 12-16 and study period of 10 weeks. In this context, researching more centres, using different test batteries, extending the practice period, practising in different age and disability groups will make significant contributions to the literature on the effects of hemsball sport.

\section{Authors' Contributions}

Meltem Işık worked on the subject of the manuscript, research design and data collection. İbrahim Kılıç worked on data analysis and reporting of the study. 


\section{References}

Akandere, M., Baştuğ, G., Asan, R., \& Baştuğ, K. (2010, May 21-23). The effect of educational game over attention in children [Paper presentation]. International Scientific Conference 'Perspectives in Physical Education and Sport, Constanta, Romania.

Anna, P., \& Magdalena, J. K. (2008). Prognostic factors for vestibular impairment in sensorineural hearing loss. European Archives of Oto-Rhino-Laryngology, 265(4), 403-407. https://doi.org/10.1007/s00405-007$\underline{0473-\mathrm{Z}}$

Assaiante, C., Mallau, S., Viel, S., Jover, M., \& Schmitz, C. (2005). Development of postural control in healthy children: A functional approach. Neural Plasticity, 12(2-3), 109-118. https://doi.org/10.1155/np.2005.109

Ayanniyi, O., Adepoju, F. A., \& Mbada, C. E. (2014). Static and dynamic balance in school children with and without hearing impairment. Journal of Experimental and Integrative Medicine, 4(4), 245-248. https://doi.org/10.5455/jeim.040814.or.109

Bruininks, R. H. (1978). Bruininks-Oseretsky Test Of Motor Proficiency. American Guidance Service.

Bruininks, R. H., \& Bruininks, B. (2005). Bruininks-Oseretsky Test Of Motor Proficiency (2nd ed.). NCS Pearson.

Butterfield, S. A. (1991). Influence of age, sex, hearing loss, and balance on development of running by deaf children. Perceptual and Motor Skills, 73(2), 624-626. https://doi.org/10.2466/pms.1991.73.2.624

Brickenkamp, R., Bleck, I., Dzida, W., Heinrich, P., Hellwig, H. J., Krüger-Naumann, R., Rothe, R., Speck, D., Speck, R., \& Thiede, L. (1975). Handbuch psychologischer undpaedagogischertests. Verlag für Psychologie.

Brunner, Y. Y. (2006). Luçse, çem supervnimaniye. Feniks.

Chilosi, A. M., Comparini, A., Scusa, M. F., Berrettini, S., Forli, F., \& Battini, R. (2010). Neurodevelopmental disorders in children with severe to profound sensorineural hearing loss: A clinical study. Developmental Medicine and Child Neurology, 52(9), 856-862. https://doi.org/10.1111/j.1469-8749.2010.03621.x

Dane, S., \& Erzurumluoğlu, A. (2003). Sex and handedness differences in eye-hand visual reaction times in handball players. International Journal of Neuroscience, 113(7), 923-929. https://doi.org/10.1080/00207450390220367

Davis, T. L., \& Fang, J. (1993). Measuring simple reaction time, choice reaction time and movement time using BASIC. Computer Methods and Programs in Biomedicine, 40(2), 147. https://doi.org/10.1016/01692607(93)90008-9

Du Toit, P. J., Kruger, P. E., Mahomed, A. F., Kleynhans, M., Jay-du Preez, T., Govender, C., \& Mercier, J. (2011). The effect of sports vision exercises on the visual skills of university students: Sport science. African Journal for Physical Health Education, Recreation and Dance, 17(3), 429-440. https://doi.org/10.4314/ajpherd.v17i3.71094

Dummer, G. M., Haubenstricker, J. L., \& Steward, D. A. (1996). Motor skill performances of children who are deaf. Adapted Physical Activity Quarterly, 13(4), 400-414. https://doi.org/10.1123/apaq.13.4.400

Foundriat, B. A., Difabio, R. P., \& Anderson, J. H. (1993). Sensory organization of balance responses in children 3-6 years of age: A normative study with diagnostic implications. International Journal of Paediatric Otorhinolaryngology, 27(3), 255-271. https://doi.org/10.1016/0165-5876(93)90231-Q

Gatehouse, S., \& Akeroyd, M. (2006). Two-eared listening in dynamic situations. International Journal of Audiology, 45(1), 120-124. https://doi.org/10.1080/14992020600783103

Genç, A. (2019). Yenidoğan işitme taraması ve erken müdahale el kitabı [Newborn hearing screening and early intervention manual]. Hipokrat Kitabevi.

Gheysen, F., Loots G., \& Waelvelde, H. V. (2008). Motor development of deaf children with and without cochlear implants. Journal of Deaf Studies and Deaf Education, 13(2), 215-224. https://doi.org/10.1093/deafed/enm053 

ADOLESCENTS WITH HEARING LOSS

Gönülateş, S. (2017). Her yaş için spor hemsball [Sport hemsball for all ages]. Akademisyen Kitabevi.

Güneş, M. (1997). İlkokul öğrencilerinin okuma düzeyleri ve dikkat özelliklerinin bazı değișkenleraçısından incelenmesi [An examination of the reading levels and attention features of elementary students according to a number of variables] (Tez Numaras1: 63214) [Yüksek lisans tezi, Gazi Üniversitesi]. Yükseköğretim Kurulu Ulusal Tez Merkezi.

Hemsball. (n.d.). History of hemsball. http://www.hemsball.com/9-tarihce.html

Hamsher K. de S., \& Benton A. L. (1977). The reliability of reaction time determinations. Cortex, 13(3), 306-310. https://doi.org/10.1016/s0010-9452(77)80040-3

Işı, M. (2016). Zihinsel engelli çocuklarda hemsball oyun becerilerinin motor yeterlik sonuçlarına etkisi [The effects of the game hemsball on the motor skills proficiency results of mentally disabled children] (Tez Numarası: 426978) [Doktora tezi, Gazi Üniversitesi]. Yükseköğretim Kurulu Ulusal Tez Merkezi.

Işık, M., \& Zorba, E. (2020). The effects of hemsball on the motor proficiency of students with intellectual disabilities. International Journal of Developmental Disabilities, 66(2), 104-112. https://doi.org/10.1080/20473869.2018.1488534

Jeyanthi, S., Arumugam, N., \& Parasher, R. K. (2019). Effect of physical exercises on attention, motor skill and physical fitness in children with attention deficit hyperactivity disorder: A systematic review. ADHD Attention Deficit and Hyperactivity Disorders, 11(2), 125-137. https://doi.org/10.1007/s12402-018-0270$\underline{0}$

Karaduman, B. D. (2004). Dikkat toplama ĕgitim programının ilköğretim 4. ve 5. sinıf öğrencilerinin dikkat toplama düzeyi, benlik alglsl ve başarl düzeylerine etkisi [The effect of attention training program on fourth and fifth grade primary school students' attention, self concept and achievement levels] (Tez Numarası: 205199) [Doktora tezi, Ankara Üniversitesi]. Yükseköğretim Kurulu Ulusal Tez Merkezi.

Kegel, A. D., Dhooge, I., Peersman, W., Rijckaert, J., Baetens, T., Cambier, D., \& Waelvelde, H. V. (2010). Construct validity of the assessment of balance in children who are developing typically and in children with hearing impairments. Physical Therapy, 90(12), 1783-1794. https://doi.org/10.2522/ptj.20100080

Kelly, D. P., Kelly, B. J., Jones, M. L., Moulton, N. J., Verhulst, S. J., \& Bell, S. A. (1993). Attention deficits in children and adolescents with hearing loss. American Journal of Diseases of Children, 147(7), 737-741. https://doi.org/10.1001/archpedi.1993.02160310039014

Kimitaka, K. (1999). Vestibular compensation in infants and children with congenital and acquired vestibular loss in both ears. International Journal of Pediatric Otorhinolaryngology, 49(3), 215-224. https://doi.org/10.1016/S0165-5876(99)00206-2

Kurt, A. (2007). Düzenli egzersizin işitme engelli ve normal bireylerde denge parametreleri üzerine etkisi [The effect of regular exercise on the people with hearing loss and healty people according to balance parameters] (Tez Numarası: 194891) [Yüksek lisans tezi, Erciyes Üniversitesi]. Yükseköğretim Kurulu Ulusal Tez Merkezi.

Majlesi, M., Farahpour, N., Azadian, E., \& Amini, M. (2014). The effect of interventional proprioceptive training on static balance and gait in deaf children. Research in Developmental Disabilities, 35(12), 3562-3567. https://doi.org/10.1016/j.ridd.2014.09.001

Mancas, M. (2016). What is attention? In M. Mancas, V. P. Ferrera, N. Riche, \& J. G. Taylor (Eds.), From human attention to computational attention (10th ed., pp. 9-20). Springer. https://doi.org/10.1007/978-1-49393435-5 2

Melo, R. S., Lemos, A., Mackyc, C. F. D. S. T., Raposoa, M. C. F., \& Ferraz, K. M. (2015). Postural control assessment in students with normal hearing and sensorineural hearing loss. Brazilian Journal of Otorhinolaryngology, 81(4), 431-438. https://doi.org/10.1016/j.bjorl.2014.08.014

Melo, R. S., Lemos, A., Paiva, G. S., Ithamar, L., Lima, M. C., Eickmann, S. E., Ferraz, K. M., \& Belian, R. B. (2019). Vestibular rehabilitation exercises programs to improve the postural control, balance and gait of children with sensorineural hearing loss: A systematic review. International Journal of Pediatric Otorhinolaryngology, 127, 109650. https://doi.org/10.1016/j.ijporl.2019.109650 
Michaëlis, S. (2013). Dikkat eksikliği ve 5 önemli sebebi [Attention deficit and its 5 important causes]. https://sassmart.com/bulletin/69-dikkat-eksikligi-ve-5-onemli-sebebi

Mülazımoğlu-Ballı, O. (2006). Bruininks-Oseretsky Motor Yeterlik Testinin geçerlik, güvenirlik çalışması ve beşaltı yaş grubu çocuklara uygulanan cimnastik eğitim programının motor gelişime etkisinin incelenmesi [The study of validity and reliability of Bruininks Oseretsky Motor Proficiency Test and the effects of gymnastics education program on motor development of five-six years-old children] (Tez Numarası: 182428) [Doktora tezi, Ankara Üniversitesi]. Yükseköğretim Kurulu Ulusal Tez Merkezi.

Olszewska, E., \& Trzcińska D. (2010). Posture of children and youth with hearing loss. Polish Journal of Sports Medicine, 26(3), 185-186. https://medycynasportowa.edu.pl/resources/html/article/details?id=19819

Patel, H., Malawade, M., Butte-Patil, S., Khairnar, P., \& Gawade, S. (2017). Comparison of balance in children with and without hearing impairment. International Journal of Healthcare and Biomedical Research, 5(2), 19-27. http://ijhbr.com/pdf/January\%202017\%2019-27.pdf

Perrin, P., Deviterne, D., Hugel, F., \& Perrot, C. (2002). Judo, better than dance, develops sensorimotor adaptabilities involved in balance control. Gait Posture, 15(2), 187-194. https://doi.org/10.1016/s0966$\underline{6362(01) 00149-7}$

Potter, C. N., \& Silverman, L. N. (1984). Characteristics of vestibular function and static balance skills in deaf children. Physical Therapy, 64(7), 1071-1075. https://doi.org/10.1093/ptj/64.7.1071

Rajendran, V., \& Roy, F. G. (2011). An overview of motor skill performance and balance in hearing impaired children. Italian Journal of Pediatrics, 37(1), 33-37. https://doi.org/10.1186/1824-7288-37-33

Rine, R. M., Braswell, J., Fisher, D., Joyce, K., Kalar, K., \& Shaffer, M. (2004). Improvement of motor development and postural control following intervention in children with sensorineural hearing loss and vestibular impairment. International Journal of Pediatric Otorhinolaryngology, 68(9), 1141-1148. https://doi.org/10.1016/j.ijporl.2004.04.007

Savelsbergh, G. J. P., Netelenbos, J. B., \& Whiting, H. T. A. (1991). Auditory perception and the control of spatially coordinated action of deaf and hearing children. Journal of Child Psychology and Psychiatry, 32(3), 489-500. https://doi.org/10.1111/j.1469-7610.1991.tb00326.x

Sever, O., Gönülateş, S., Bayraktar, A., Zorba, E., Gerek, Z., \& İpekoğlu, G. (2016). The effect of 8-week hemsball training on balance, reactive agility and lower extremity strength. Turkish Journal of Sport and Exercise, 18(3), 78-83. https://dergipark.org.tr/tr/pub/tsed/issue/27254

Shah, J., Rao, K., Malawade, M., \& Khatri, S. (2013). Effect of motor control program in improving gross motor function and postural control in children with sensorineural hearing loss-a pilot study. Pediatrics \& Therapeutics, 3(1), 1000141. https://doi.org/10.4172/2161-0665.1000141

Siegel, J. C., Marchetti, M., \& Tecklin, J. S. (1991). Age-related balance changes in hearing impaired children. Physical Therapy, 71(3), 183-189. https://doi.org/10.1093/ptj/71.3.183

Silsupadol, P., Siu, K. C., Shumway-Cook, A., \& Woollacott, M. H. (2006). Training of balance under single- and dual-task conditions in older adults with balance impairment. Physical Therapy, 86(2), 269-281. https://doi.org/10.1093/ptj/86.2.269

Stanek, E., Truszczynska, A., Drzal-Grabiec, J., \& Tarnowski, A. (2015). Postural balance assessment in children aged 7 to 9 years, as related to body weight, height, and physical activity. Biomedical Human Kinetics, 7(1), 135-141. https://doi.org/10.1515/bhk-2015-0020

Tetik, S., Koç, H., \& Atar, O. (2016). An Analysis of selected motor characteristics according to age groups in hearing-impaired individuals. Studies on Ethno-Medicine, 10(3), 295-300. https://doi.org/10.1080/09735070.2016.11905500

Todorova, R., Dimkova R., Valova, T., \& Marcheva, P. (2014). Hemsball game and its influence on handicapped children's psychophysical condition and the family's opinion. International Journal of Science Culture and Sport, 2(1), 665-693. https://dergipark.org.tr/tr/download/article-file/91688 
Tunç, A., Akandere, M., \& Baştuğ, G. (2014). The analysis of the attention levels of individuals playing golf. Turkish Journal of Sport and Exercise, 16(1), 104-115. https://dergipark.org.tr/en/download/articlefile/200689

Theunissen, S., Rieffe, C., Kouwenberg, M., Raeve, L., Soede, W., Briaire, J. J., \& Frijns, J. (2014). Behavioral problems in school-aged hearing-impaired children: The influence of sociodemographic, linguistic, and medical factors. European Child \& Adolescent Psychiatry, 23(4), 187-196. https://doi.org/10.1007/s00787-013-0444-4

Ural, A., \& Kılıç, İ. (2011). Bilimsel araştırma süreci ve SPSS ile veri analizi [Scientific research process and data analysis with SPSS] (3. bask1). Detay Yayıncılık.

Üçüncü, M., \& Kütükcü, Ş. (2014). Özel eğitimde araç ve materyal geliştirme [Tool and material development in special education]. Vize Basin Yayın.

Yurdakul, A., Çamlıyer, H., Çamlıyer, H., Karabulut, N., \& Soytürk, M. (2012). The effects of movement education on attention and memory development in the age group of 8 years children. Selcuk University Journal of Physical Education and Sport Science, 14(1), 103-108. https://doi.org/10.14486/IntJSCS488

Walowska, J., Bolach, B., \& Bolach, E. (2018). The influence of pilates exercises on body balance in the standing position of hearing impaired people. Disability and Rehabilitation, 40(25), 3061-3069. https://doi.org/10.1080/09638288.2017.1370731

World Health Organization. (2021). Deafness and hearing loss. https://www.who.int/news-room/factsheets/detail/deafness-and-hearing-loss 


\section{Ankara Üniversitesi Eğitim Bilimleri Fakültesi Özel Eğitim Dergisi}

2022, 23(2), 389-407
ARAŞTIRMA

Gönderim Tarihi: 13.01.21

Kabul Tarihi: 28.07.21

Erken Görünüm: 18.09.21

\title{
Hemsball'da Komplike Egzersizlerin İşitme Engelli Çocukların Dikkat ve Koordinatif Becerilerine Etkisi*
}

\author{
Meltem Işsk $(\mathbb{D}) 1$
}

\author{
İbrahim KılıçiD2
}

$\ddot{\mathbf{O} z}$

Giriş: $\mathrm{Bu}$ araştırmada, hemsballda komplike egzersizlerin işitme engellilerin dikkat ve koordinatif yetilerine etkisinin belirlenmesi amaçlanmıştır.

Yöntem: Çalışmaya, 10 deney grubu, 10 kontrol grubu olmak üzere toplam 20 işitme engelli çocuk katılmıştır. Çalı̧̧malara katılan işitme engelli çocuklara haftada 3 gün birer saat olmak üzere 10 hafta süreyle hemsballda komplike alıştırmalardan oluşan bir egzersiz programı uygulanmıștır. Veri toplama tekniği olarak bourdon dikkat testi, basit reaksiyon zamanı testi, BOT-2 motor yeterlik alt maddelerinden denge testi ve el-göz koordinasyon ölçümleri için alternatif el duvar firlatma testi kullanılmıştır. Elde edilen verilerin analizinde betimsel istatistiklerin yanı sıra her bir gruba ilişkin öntest ve sontest ortalamaları arasındaki farklılık için tekrarlı ölçümler için iki faktörlü varyans analizi kullanılmıştır.

Bulgular: Araştırma sonucunda, deney grubunda hemsballda komplike egzersiz programının dikkat, el-göz koordinasyonu, denge ve reaksiyon testi (baskın el) üzerinde anlamlı bir etkisi olduğu görülürken, reaksiyon test (baskın olmayan el) ortalamaları arasında anlamlı bir farklılık görülmemiştir.

Tartışma: Yapılan araştırmalarda, dikkat ve koordinasyon bozukluğu olan işitme engelli çocuklarda ihtiyaçlara göre uyarlanmış egzersiz programlarını geliştirmek ve teşvik etmek özellikle önemli görülmektedir.

Sonuç: Bu çalı̧̧mada belirtilen komplike hemsball egzersizleri, dikkat, odaklanma ve konsantrasyon, el-göz-ayak koordinasyonu, denge ve reaksiyon hızı açısından işitme kaybı olan çocuklar için alternatif bir aktivite olarak düşünülmelidir.

Anahtar sözcükler: Hemsball, işitme engelli, egzersiz, dikkat, bot-2, koordinasyon, reaksiyon zamanı.

Atıf için: Işık, M., \& Kılıç, İ. (2022). Hemsball'da komplike egzersizlerin işitme engelli çocukların dikkat ve koordinatif becerilerine etkisi. Ankara Üniversitesi Ĕ̆itim Bilimleri Fakültesi Özel Ĕgitim Dergisi, 23(2), 389-407. https://doi.org/10.21565/ozelegitimdergisi.859721

*Bu çalışma Afyon Kocatepe Üniversitesi Bilimsel Araştırma Projeleri Komisyonu tarafından desteklenmiştir (Proje no:17.BESYO.04).

${ }^{1}$ Sorumlu Yazar: Dr. Öğr. Üyesi, Afyon Kocatepe Üniversitesi, E-posta: isik.meltem@ adu.edu.tr, https://orcid.org/0000-00021372-9322

${ }^{2}$ Prof. Dr., Afyon Kocatepe Üniversitesi, E-posta: kilicibrahim@hotmail.com, https://orcid.org/0000-0003-0595-8771 


\section{Giriş}

İşitme engelli çocuklar, oturma, emekleme, destekli yürüme, desteksiz yürüme gibi temel motor gelişim aşamalarından işiten çocuklarla benzer sürelerde geçmektedirler. Ancak işitme kaybının sebebine ve derecesine bağlı olarak, dengede, eşdeğer reaksiyonlarda ve kas koordinasyonu ile ilgili becerilerde daha yetersiz oldukları gözlenmektedir (Olszewska, \& Trzcińska, 2010; Rine vd., 2004; Üçüncü, \& Kütükcü, 2014). Motor koordinasyon ve denge duyusuna liderlik eden vestibüler sistemin etkilenmesi sonucu kas kontrolünde ve dengede meydana gelebilecek problemler, kas kuvvetini ve motor fonksiyonları da olumsuz yönde etkilemektedir. (Kegel vd., 2010, Rajendran, \& Roy, 2011; Shah vd., 2013). Diğer bir ifadeyle işitsel duyumları alamamak, en sık yapılan hareketleri daha koordinasyonsuz hale getirir; vücut dengesi kontrolü bozulur (Anna \& Magdalena, 2008). İşitme engelli çocuklarda motor becerilerle ilgili yapılan bazı çalıșmalar, statik ve dinamik denge, genel dinamik koordinasyon, görsel motor beceriler ve top yakalama becerilerinde azalma ve reaksiyon süreleri ile hareket hızlarında belirgin farklılıklar olduğunu göstermiştir (Chilosi vd., 2010; Melo vd., 2019; Rine vd., 2004). Günlük motor aktiviteler sırasında kullanılan temel koordinasyon becerilerinden birisi dengeyi sağlamaktır (Stanek vd., 2015). Bu nedenle, işitme kaybı olan kişilerin düzenli fiziksel aktiviteye katılmaları ve özellikle güç ve dengeyi geliştiren özel egzersizler yapmaları teşvik edilmelidir (Assaiante vd., 2005). Yapılan sportif aktivite, antrenman ve egzersiz tutarlılığının sağlanması bu kişilerin gün boyu dinamik ve statik postüral kontrolünde etkili olacaktır (Ayanniyi vd., 2014; Patel vd., 2017; Perrin vd., 2002). Doğum sonrası edinilen işitme engeli olan birçok öğrencinin, doğuştan olan işitme engelli akranlarına göre dikkat problemi yaşadığı ayrıca Amerika Birleşik Devletleri ve Yugoslavya'da yapılan çalışmalarda da işitme engelli çocukların işiten akranlarına göre yüksek düzeyde dikkat eksikliği gösterdikleri bildirilmiştir (Kelly vd., 1993). Theunissen ve diğerleri (2014), işitme engelli çocukların normal işiten akranlarına göre çok daha fazla dikkat eksikliği gösterdiğini bildirmiştir. İşitme engelli çocukların dikkat eksikliği gösterdiğini gösteren çalışmalar olmasına rağmen, bu çocuklarda fiziksel egzersizin dikkat eksikliği üzerindeki etkisini araştıran herhangi bir çalışma bulunamamıştır. Öte yandan yürüme, koşma, zıplama ve top oyunları gibi çeşitli egzersiz programlarının dikkat eksikliği olan çocuklarda karakteristik dikkat eksikliği belirtilerini hafiflettiği bulunmuştur. Çocukların motor aktivitesinin gelişimi ve temel fiziksel özellikleri ve organizmaların güçlenmesini sağlayan en önemli faktör oyundur. Yeni bir spor olan ve herkes tarafindan oynanabilen Hemsball, topu tutabilmek ve servis atabilmek için mükemmel el-göz-ayak koordinasyonuna, oyun esnasında rakibin yapacağı hamlelere karşı yüksek odaklanma ve konsantrasyona, topu yakalama esnasında denge yetisine ayrıca rakibin gönderdiği atışlara yapılan ani hamlelerde reaksiyon hızına sahip olmayı gerektirmektedir (Işık \& Zorba, 2020). Hemsball oyununun amac1, hemsball topunu yerde bulunan hemsball hedef tahtası üzerindeki hemsball çemberinin içine, çembere çarptırmadan göndererek rakip oyuncunun alanında yere değmesini sağlamak ve rakip oyuncunun aynı amaca ulaşmasını önlemektir. Koordinatif yetilerin geliştirilmesinde ve hemsball spor becerisinde dominant ele bakılmaksızın her iki elin de aktif olarak kullanılmasını sağlayan, birden fazla top ile yapılan hakimiyet çalışmalarını içeren komplike egzersizler önemli bir yer tutmaktadır. Bu bağlamda; uygulanacak çalışma, işitme engelli çocukların dikkat ve koordinatif yetilerine olan etkisini ortaya koyması bakımından önemli görülmektedir. Yukarıdaki bilgiler çerçevesinde bu araștırmada, Hemsball'da hazırlık kademesinde verilmesi gereken komplike egzersizlerin işitme engellilerin dikkat ve koordinatif yetilerine etkisinin belirlenmesi amaçlanmıştır.

\section{Yöntem}

\section{Araștırma Deseni ve Katılımcılar}

Bu çalışma öntest/sontest kontrol gruplu desen niteliğindedir. Öntest/sontest kontrol gruplu desen, birisi tekrarlı ölçümleri (öntest ve sontest), diğeri de farklı kategorilerde bulunan denekleri (deney ve kontrol grupları) gösteren iki faktörlü bir deneysel desen olarak belirtilmektedir (Ural \& Kılıç, 2011). Araştırmanın veri grubunu Afyonkarahisar ve Kütahya ilinde bulunan Karahisar işitme engelliler okulu ve Kütahya işitme engelliler okuluna giden 12 ile16 yaş aralığında olan, işitme kaybı 56 dB üzerinde, ikinci bir engeli ve spor geçmişi olmayan çocuklar oluşturmaktadır. Çalışmaya 10’u deney grubu, 10’u kontrol grubu olmak üzere toplam 20 işitme engelli öğrenci katılmıştır. Çalışmaya katılan işitme engelli çocukların ebeveynleri yazılı bilgilendirilmiş onam formu imzalamıştır. Hemsball egzersizlerine başlamadan önce katılan çocukların velileri ile bir toplantı yapılmış, toplantıda hemsball egzersiz programının içeriği hakkında bilgi verilmiştir. Çalışmaya dahil edilen deney grubunda bulunan işitme engelli çocuklara, haftada 3 gün birer saat olmak üzere 10 hafta süreyle hemsball komplike alıştırmalarından oluşan bir egzersiz programı uygulanmıştır. 

BECERILERINE ETKISI

\section{Egzersiz Programı}

Hemsball ilk olarak 2011 yılında Altınay tarafindan tasarlanmıș olup, 2013 yılında Türkiye Cumhuriyeti Gençlik ve Spor Bakanlığı tarafından spor dalı olarak kabul edilmiştir. Türkiye Herkes İçin Spor Federasyonu 2014 yılında hemsball için antrenörlük kurslarına başlamıştır. Bu antrenörlük kursları ve seminerlerinde hemsball oyun kuralları atış teknikleri ve hemsball uygulamaları ilk kez tanıtılmıştır (Hemsball, t.y.). Oyun kuralları, teknikler ve uygulamaları içeren "Her yaş için spor Hemsball" ilk olarak 2017 yılında yayınlandı (Gönülateş, 2017). Çalışmada yer alan komplike egzersiz programı (Gönülateş, 2017; Hemsball, t.y.) işitme engellilere uyarlanmıştır. Bu çalışmanın deney grubuna dahil edilen işitme engelli çocuklar, 10 hafta boyunca haftada 3 gün ve 1 saat hemsball komplike egzersizlerinden oluşan bir eğitim programına tabii tutulmuştur. Deney grubuna uygulanan hemsball komplike egzersiz programı aşağıda sunulmuştur.

\section{Hemsball Komplike Egzersiz Programı}

Isınma hareketleri, topu sağ elle havaya atıp sol elle, sol elle havaya atıp sağ elle tutma, topu üç parmak ile saat yönünde döndürerek havaya atma ve yere düşmeden aynı/zıt el ile yakalama, ayaklar sabit el değiştirerek topu yerde sektirme, ileri/geri yürüyerek top sektirme, tutulan topu baş üstü seviyesinde tek el ve el değiştirerek duvara atıp tutma, duvara iki metre mesafede oturarak yerden duvara atılan topu aynı/zıt el yakalamak ile başlar.

Hemsball komplike hareketlere geçilir. 1-Duvarın önünden uzaklaşarak yerleştirilen üç adet çemberin içine gelecek şekilde üç metre mesafeden sırayla hemsball topunu atmak. 2-Daire düzeninde dizilen çemberlerin merkezinde bulunan öğrenci saat yönünde dönerek her çemberin içine topu atıp yakalar. 3-Her iki elde tutulan birer hemsball topu aynı zamanda yere atılır ve çapraz olarak yakalanır. 4-Duvarın önüne koyulan hedef tahtasına bir metre mesafede yerleştirilen ayak basma tablasının üzerindeki öğrenci elindeki hemsball topunu hedef tahtasındaki kırmızı noktaya atar ve duvardan dönen topu yakalar. 5-İki öğrenci aralarında üç metre mesafe olacak şekilde karşılıklı geçer ve her birinde bir hemsball topu vardır. Aynı anda ikisi de birbirine topu yukarıdan atar ve karşıdan gelen topu tutmaya çalışır. 6-Aynı çalışma yerden sektirerek de yapılır.7-Duvara yüzü dönük 2 metre mesafede öğrenci her iki elinde tuttuğu hemsball toplarını aynı anda yerden duvara atar ve dönen topu yakalar. 8Duvara yüzü dönük 2 metre mesafede öğrenci aynı elde tuttuğu hemsball toplarını sırayla yerden duvara atar ve aynı taraf ile atma yakalama çalışmasına devam eder. 9-Öğrencinin tek elinde tuttuğu iki hemsball topu sırasıyla yukarı atılır ve düşürmeden tek top hep yukarıda olacak şekilde tek el aktif olarak çalışma devam eder. 10-Öğrenci bir elinde tuttuğu iki topu diğer elinde tuttuğu bir top ile sırasıyla havaya atıp yakalamaya çalışır (üç top çevirme). Germe hareketleri ile çalışma biter.

\section{Verilerin Toplanması}

Veriler, dikkat ve koordinatif beceri testleri yoluyla toplandı. İşitme engellilerin dikkat düzeyleri bourdon dikkat testi (Brickenkamp vd., 1975; Brunner, 2006) ile koordinatif beceri düzeyleri ise basit reaksiyon zamanı testi (Davis \& Fang, 1993), BOT-2 denge testi (Bruininks \& Bruininks 2005) ve el-göz koordinasyonu için alternatif el duvar firlatma testi (Du Toit vd., 2011) ile değerlendirilmiştir. Tepki testi milisaniye cinsinden değerlendirilirken, bourdon dikkat testi, BOT-2 denge testi ve alternatif el duvar firlatma testi puan olarak değerlendirilmiştir.

\section{Bourdon Dikkat Testi}

İșitme engelli çocuklara verilen kâğgtlar belli ve düzenli aralıklarla sıralanmış 407 harf ve 20 satırdan oluşur. Deneme kâğıtlarında a (150 adet), g (75 adet), b (50 adet) ve d (25 adet) harfleri bulunur. Her bölümün süresi beş dakikadır. Çocuklardan tanınan süre zarfında her satırı sırayla takip ederek belirtilen harflerin altını çizmeleri istenmiş ve verilen süre sona erdiğinde altı çizilen harfler sayılarak testin değerlendirmesi yapılmıştır. Testten alınabilecek en yüksek puan 118 puan olarak belirlenmiştir (Brunner, 2006). Burdon dikkat testi için Cronbach Alpha katsayısı Karaduman (2004) tarafından 0.78 olarak bildirilmiştir.

\section{Basit Reaksiyon Zamanı Testi}

Ölçüm sırasında, çocukların dikkatlerini dağıtıcı faktörler uzaklaştırılarak sessiz bir oda ile yeterli ışık sağlanmıştır. Işığa karşı reaksiyon testi için hem sağ hem de sol işaret parmakları için üç tekrar alınmıştır. Test sırasında gözler ekranın $40 \mathrm{~cm}$ arkasında kalacak şekilde ekrana odaklandı. Çocuklardan düğmeyi sağ ve sol ellerini ve işaret parmağını kullanarak düğmenin yaklaşık $1 \mathrm{~cm}$ yukarısında tutmaları istendi. $150 \mathrm{~ms}$ 'den kısa görsel reaksiyon süreleri beklenen yanıt olarak kabul edilirken, 500 ms'den uzun görsel reaksiyon süreleri önemli hatalar olarak kabul edildi. Her ikisi de analizlerden çıkarıldı. Görsel reaksiyon süresi (ms) ortalama ve standart 
sapmalar olarak ifade edildi (Dane \& Erzurumluoğlu, 2003). Basit reaksiyon zamanı testi için Cronbach Alpha katsayısı Hamsher and Benton (1977) tarafından 0.93 olarak bildirilmiştir.

\section{BOT-2 Denge Testi}

Bruininks-Oseretsky motor yeterlik denge testi 9 bölümden oluşmaktadır (Bruininks, 2005). 1-Gözler açık ayaklar öne açılı şekilde bir çizgi üzerinde durma. 2-Bir çizgi üzerinde ileriye doğru yürümek. 3-Gözler açık bir çizgi üzerinde tek ayakta durma. 4-Gözler kapalı ayaklar öne açılı şekilde bir çizgi üzerinde durma. 5-Bir çizgi üzerinde ayak parmak ucu ve topuk şeklinde ileri yürüme. 6-Gözler kapalı bir çizgi üzerinde tek ayakta durma. 7Gözler açık bir denge aleti üzerinde tek ayakta durma. 8-Bir denge aleti üzerinde ayakucu topuğa temas halinde durma. 9-Gözler kapalı bir denge aleti üzerinde tek ayakta durma. Test prosedürü sırasında kaydedilen puanlar, çocukların ham puanlarıdır. Test tamamlandıktan sonra bu ham puanlar nokta puana ve daha sonra elde edilen puanlara dönüştürülür. Kişisel kayıt formunda verilen dönüştürme ölçeği ham puanların nokta puanlara dönüştürülmesi için kullanılır. Nokta puanı kişisel kayıt formunun ilk sağındaki daireye kaydedilir ve toplam motor puanı hesaplanır, BOT-2 denge testi için en iyi puan 37'dir. (Mülazımoğlu-Ballı, 2006). BOT-2 denge testi için Cronba Alfa katsayısı Bruininks (1978) tarafından 0.87 olarak bildirilmiştir.

\section{Alternatif El Duvar Furlatma Testi}

Duvara iki metre mesafede bir şerit çizilir. Denekten yüzü duvara dönük, ayaklar omuz genişliğinde açık, dizler bükülü pozisyonda durması istenir. Sağ veya sol eli ile tuttuğu tenis topunu duvara atıp, topu atmadığı eli ile yakalaması istenir. $30 \mathrm{sn}$. süre tutulur ve başarılı yakalayışlar kaydedilir. Üç deneme yapılmasına izin verilir ve en iyi puan kaydedilir. Puan tablosunda belirtilen skora göre gerekli hesaplamalar amaca uygun olarak doğru bir şekilde yapılır. Tabloya göre yakalama, 35 'in üzerinde çok iyi ve 15 'in altında zayıf olarak değerlendirilmiştir. Ölçümler işin başlamasından 3 gün önce ve iş bitiminden 3 gün sonra yapılmıştır (Du Toit, 2011). Alternatif el ile topu duvara atma testi için güvenilirlik ve geçerlilik verisi bulunamadı.

Ölçümler, çalışmalar başlamadan birkaç gün önce ve çalışmalar sona erdikten birkaç gün sonra yapılmıştır. Ölçümlerin nasıl yapılacağı bütün çocuklara işaret dili sertifikası olan gönüllü tercümanlar tarafından anlatılarak, öğrenmenin gerçekleşmesi için ölçümlerden önce çalışma grubunun tamamına deneme ölçümleri yaptırılmıştır. Ölçümlerin yapılacağı ortam sessiz ve çocukların dikkatinin dağılmayacağı şekilde düzenlenmiştir.

\section{Verilerin Analizi}

Araştırma kapsamında işitme engelli çocukların bireysel özellikleri frekans $(f)$ ve yüzde (\%) dağılımıyla betimlenmiştir. Verilerin test sonuçları (Kolmogorov-Simirnov testi, Shapiro-Wilk testi) normal dağılımla orantılıydı. $\mathrm{Bu}$ bağlamda, çalışmanın örneklem grubunu oluşturan çocuklarda kullanılan hemsball atış tekniklerinin etkisi, tekrarlanan ölçümler için iki faktörlü (grup $\mathrm{x}$ zaman) varyans analizi kullanılarak değerlendirilmiş, anlamlılık düzeyi ise $p<.05$ olarak belirlenmiştir. Ancak, varyans analizi sonucunda grup ve zaman etkileşimi anlamlı bulunmamıştır. Bu nedenle, farklılıkları detaylı olarak incelemek için gruplar arasındaki farklılıklar bağımsız örnekler $\mathrm{t}$ testi ile, ön test ve son test arasındaki farklar ikili örneklem $\mathrm{t}$ testi ile analiz edilmiştir. Elde edilen veriler SPSS 18.0 for Windows programı ile analiz edilmiştir.

\section{Bulgular}

İşitme engelli çocuklarda hemsball komplike alıştırmalarının dikkat ve koordinatif yetiler üzerindeki etkisine bakıldığında deney grubunun dikkat, el-göz koordinasyonu, denge ve reaksiyon (baskın el) ön-test ve sontest ortalamaları arasında anlamlı bir farklılık bulunmuştur $(p<.05)$. Kontrol grubunda ise tüm ön-test ve son-test ortalamaları arasındaki fark önemli bulunmamıştır $(p>.05)$. Aritmetik ortalama değerleri incelendiğinde; deney grubunda dikkat $\bar{X}=88.10$ 'dan $\bar{X}=107.50$ 'ye, el-göz koordinasyonu $\bar{X}=7.30$ 'dan $\bar{X}=13.30$ 'a ve denge $\bar{X}=$ 28.30 'dan $\bar{X}=33.90$ 'a yükseldiği, reaksiyon skorunun ise $\bar{X}=51.30$ 'dan $\bar{X}=38.30$ 'a düştüğü belirlenmiştir. Ayrıca, dikkat ve koordinatif yetiler ön-test ortalamalarına göre deney ve kontrol grupları arasında anlamlı bir farklılık bulunmazken ( $p>.05$ ), dikkat, el-göz koordinasyonu, denge son testlerinde deney ve kontrol grupları arasında anlamlı bir farklılık gözlenmiştir $(p<.05)$. Diğer taraftan, reaksiyon (baskın olmayan el) bakımından gerek deney ve kontrol gerekse ön-test veya son-test ortalamaları arasında anlamlı bir farklılık tespit edilmemiştir $(p>.05)$. Hemsball komplike alıştırmaların dikkat ve koordinatif yetiler üzerindeki etkisine yönelik bulgular, Tablo 1'de sunulmuştur. 
Tablo 1

Hemsball Komplike Alıştırmaların Dikkat ve Koordinatif Yetiler Üzerindeki Etkisine Yönelik Bulgular

\begin{tabular}{|c|c|c|c|c|c|c|}
\hline \multirow{2}{*}{ Koordinatif yetiler } & \multirow{2}{*}{ Gruplar } & \multicolumn{2}{|c|}{ Ön test } & \multicolumn{2}{|c|}{ Son test } & \multirow[b]{2}{*}{$p$} \\
\hline & & $\bar{X}$ & $S S$ & $\bar{X}$ & $S S$ & \\
\hline \multirow{3}{*}{ Dikkat testi } & Deney & 88.10 & 19.39 & 107.50 & 11.25 & $<.05$ \\
\hline & Kontrol & 89.20 & 18.13 & 89.60 & 19.34 & $>.05$ \\
\hline & $p$ & \multicolumn{2}{|c|}{$>.05$} & \multicolumn{2}{|c|}{$<.05$} & \\
\hline \multirow{3}{*}{ El-göz koordinasyon testi } & Deney & 7.30 & 3.83 & 13.30 & 4.27 & $<.05$ \\
\hline & Kontrol & 11.80 & 8.91 & 12.10 & 9.19 & $>.05$ \\
\hline & $p$ & \multicolumn{2}{|c|}{$>.05$} & \multicolumn{2}{|c|}{$<.05$} & \\
\hline \multirow{3}{*}{ Denge } & Deney & 28.30 & 2.40 & 33.90 & 2.64 & $<.05$ \\
\hline & Kontrol & 25.80 & 4.66 & 26.40 & 4.74 & $>.05$ \\
\hline & $p$ & \multicolumn{2}{|c|}{$>.05$} & \multicolumn{2}{|c|}{$<.05$} & \\
\hline \multirow{3}{*}{ Reaksiyon test (baskın el) } & Deney & 51.30 & 7.87 & 38.30 & 6.34 & $<.05$ \\
\hline & Kontrol & 43.00 & 10.61 & 42.80 & 10.22 & $>.05$ \\
\hline & & \multicolumn{2}{|c|}{$>.05$} & \multicolumn{2}{|c|}{$>.05$} & \\
\hline \multirow{3}{*}{$\begin{array}{l}\text { Reaksiyon test (baskin } \\
\text { olmayan el) }\end{array}$} & Deney & 49.80 & 10.053 & 41.70 & 8.11 & $>.05$ \\
\hline & Kontrol & 49.10 & 10.98 & 49.40 & 10.26 & $>.05$ \\
\hline & $p$ & \multicolumn{2}{|c|}{$>.05^{10.90}$} & \multicolumn{2}{|c|}{$>.05$} & \\
\hline
\end{tabular}

\section{Tartışma}

El-göz koordinasyonu, dikkat, tepki ve denge odaklı komplike egzersizlerin işitme engelli çocukların koordinasyon becerilerine etkisinin belirlenmesi amacıyla gerçekleştirilen bu çalışmanın örneklem grubunu 12-16 yaş arası 20 işitme engelli öğrenci oluşturmuştur. Her iki elin de aktif olarak kullanılmasını sağlayan koordinasyon beceri egzersizleri ile çoklu top egzersizleri içeren komplike egzersizler (Gönülateş, 2017; Hemsball, t.y.) hemsball spor becerisinde önemli bir yere sahiptir. İşitme engelli çocukların dikkat ve koordinasyon becerilerinin değerlendirilmesinde, deney grubunun dikkat, el-göz koordinasyonu ve dengesinin önemli ölçüde arttı̆̆ gözlenmiştir. Hemsball komplike egzersizlerinin baskın elin reaksiyon süresi üzerinde önemli ve olumlu bir etkisi olduğu tespit edilirken uygulamanın (egzersiz) baskın olmayan elin reaksiyonu üzerinde istatistiksel olarak anlamlı bir etkisi olmadığı bulunmuştur. Hemsball'un düşük zekâ geriliği olan çoğul engelli çocukların psiko-fiziksel gelişimine (Todorova vd., 2014) ve normal bireylerde denge, tepkisel çabukluk ve alt ekstremite gücü üzerine etkilerini araştıran çalışmalar olmakla birlikte (Sever vd., 2016), Hemsball'un engelli bireylerde motor gelişim üzerindeki etkilerini araştıran ilk ayrıntılı çalışma yazar tarafından yapılmış ve doktora tezi olarak yayınlanmıştır (Işık, 2016). Zihinsel engelli çocuklarda Hemsball'un denge, ikili koordinasyon ve üst ekstremite koordinasyonuna etkisini belirlemeyi amaçlayan çalışma Işık'ın (2006) doktora tezinden alınmıştır. Düşük ve orta düzey zihinsel engelli çocuklarda 12 haftalık bir hemsball temel eğitim programının motor beceriler üzerinde olumlu etkileri olduğu bildirilmiştir. (Işık \& Zorba, 2020). İşitme kaybının zaman zaman motor becerileri etkilediği bilinmektedir. İşitme engellilerde, hareketlerin uyumu ve koordinasyonu dahil olmak üzere motor becerilerin gelişim derecesi, diğer duyu organlarının kullanımı ve eğitimi yoluyla eksiklikleri telafi etme becerisine bağlıdır (Walowska vd., 2018). Bu çalışmada, komplike hemsball egzersizlerinin işitme engelli çocuklarda denge gelişimine olumlu katk1 sağlaması şaşırtıcı değildir. Günlük motor aktivitelerde kullanılan temel koordinatif becerilerden biri dengeyi sağlamaktır. Walowska ve diğerleri (2018) tarafından yapılan bir çalışmada, modifiye pilates egzersizlerine dayalı orijinal fiziksel aktivite programına göre yapılan egzersizlerin, 13 ile 24 yaş arası işitme engelli kişilerde vücut dengesi kontrolünü iyileştirmede önemli ölçüde daha etkili olduğu bulunmuştur. Sever ve diğerleri (2016) sekiz haftalık hemsball antrenmanındaki çocukların denge puanlarının arttı̆̆ını bulmuşlardır. Hareketin koordinasyonu ve uyumu ile birlikte motor becerilerin gelişimi, işitme engellilerin eksikliklerini diğer duyu organlarının kullanılmasiyla telafi etme becerisine dayanmaktadır (Walowska vd., 2018). Bu nedenle, koordinasyonu iyileştirmek için motor fiziksel aktivitelerin teşvik edilmesi bu grupta özellikle önemli kabul edilir. Hemsball komplike egzersiz programında yer alan duvar egzersizleri, firlatılan topun dönüş hızı ve yüksekliğinin yanı sıra dönüş açısının tahmin edilmesini ve kısa sürede değerlendirilmesini gerektirir. Ayrıca topun tek el ile yakalanması ve duvara olan mesafenin sınırlandırılmasıyla zorluk derecesini artırmaktadır. Bu nedenle, alıştırmalar basit olmasına rağmen, koordinatif becerilerin kazanılmasını teşvik eder. Araştırmalarda, koordinatif yetenekleri bozulmuş işitme engelli kişilerde ihtiyaçlarına uygun egzersiz programlarının geliştirilmesi ve teşvik edilmesinin özellikle önemli olduğu vurgulanmaktadır (Gheysen vd., 2008; Melo vd., 2015; Rajendran \& Roy, 2011; Walowska vd., 2018). Tetik ve diğerleri (2016), yaşa göre gelişen tepki süresinin düzenli fiziksel aktivite ile 
azaldığını ve performansı artırdığını saptamışlardır. Bir başka araştırmada Rine ve diğerleri (2004), işitme engelli çocuklar ile yaptıkları çalışmada hareket stratejilerine odaklanan egzersiz müdahalelerinin motor gelişim gecikmesinin ilerlemesini durdurabileceğini belirtmişlerdir. Yurdakul ve diğerleri (2012) hareket öğretiminin dikkat ve hafıza gelişimi üzerinde olumlu bir etkisi olduğunu ortaya koyarken, Akandere ve diğerleri (2010) sekiz hafta süren eğitici oyun uygulamalarının beden eğitimi sınıfındaki çocukların dikkat düzeylerini etkilediğini ve eğitici oyun programının deneme grubunun dikkat değerlerinin kontrol grubuna göre daha yüksek olduğunu tespit etmişlerdir.

Hemsball oyununun bu çalışma ile işitme engellilerin dikkat ve koordinatif becerileri üzerinde pozitif etkilerinin bulunduğu belirlenmiş olup, farklı örneklem gruplarında yapılacak çalışmalar ile hem oyunun katkısı hem de tanıtımı gerçekleştirilerek hemsball konusunda çok sınırlı sayıdaki alan yazına da önemli katkılar sunulacaktır.

\section{Yazarların Katkı Düzeyleri}

Çalışmanın konusunu belirleme, araştırma tasarımı ve veri toplama konularında Meltem Işık, veri analizi ve raporlaması üzerinde İbrahim Kılıç çalışmıştır. 